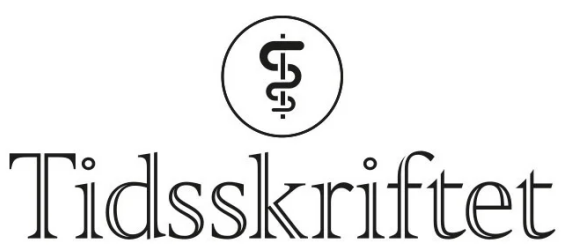

DEN NORSKE LEGEFORENING

\title{
Leishmaniasis i Norge
}

\author{
ORIGINALARTIKKEL
}

\section{KARL ERIK MÜLLER}

kamull@vestreviken.no

Medisinsk avdeling

Drammen sykehus

og

Klinisk institutt 2

Universitetet i Bergen

og

Institutt for biovitenskap

Universitetet i São Paulo

Han har bidratt med utforming av studien, innsamling og tolkning av data, førsteutkastet av manuskriptet, revisjon og godkjenning av innsendte manusversjon.

Karl Erik Müller er ph.d., lege i spesialisering og forsker med tilknytning til Forskningsgruppe for infeksjon og mikrobiologi.

Forfatteren har fylt ut ICMJE-skjemaet og oppgir ingen interessekonflikter.

\section{BJ $\varnothing R N B L O M B E R G$}

Klinisk institutt 2

Universitetet i Bergen

og

Nasjonal kompetansetjeneste for tropiske infeksjonssykdommer

Haukeland universitetssjukehus

Han har bidratt med utforming av studien, innsamling og tolkning av data, revisjon og godkjenning av innsendte manusversjon.

Bjørn Blomberg er overlege og førsteamanuensis i infeksjonssykdommer.

Forfatteren har fylt ut ICMJE-skjemaet og oppgir ingen interessekonflikter.

\section{MARIT GJERDE TELLEVIK}

Nasjonal kompetansetjeneste for tropiske infeksjonssykdommer

Haukeland universitetssjukehus

Hun har bidratt med utforming av studien, innsamling og tolkning av data, revisjon og godkjenning av innsendte manusversjon.

Marit Gjerde Tellevik er M.Sc. og spesialbioingeniør.

Forfatteren har fylt ut ICMJE-skjemaet og oppgir ingen interessekonflikter.

\section{MOGENS JENSENIUS}

Infeksjonsmedisinsk avdeling Oslo universitetssykehus, Ullevål

Han har bidratt med innsamling og tolkning av data, revisjon og godkjenning av innsendte manusversjon.

Mogens Jensenius er spesialist i infeksjonsmedisin og overlege.

Forfatteren har fylt ut ICMJE-skjemaet og oppgir ingen interessekonflikter. 
Avdeling for mikrobiologi

Oslo universitetssykehus, Ullevål

Hun har bidratt med innsamling og tolkning av data, revisjon og godkjenning av innsendte manusversjon.

Cathrine Fladeby er ph.d. og overingeniør.

Forfatteren har fylt ut ICMJE-skjemaet og oppgir ingen interessekonflikter.

\section{TORE LIER}

Referansetjenesten for serologisk parasittdiagnostikk

Avdeling for mikrobiologi og smittevern

Universitetssykehuset Nord-Norge

og

Enheten för parasitologi

Folkhälsomyndigheten

Stockholm

Han har bidratt med innsamling og tolkning av data, revisjon og godkjenning av innsendte manusversjon.

Tore Lier er ph.d., spesialist i mikrobiologi og overlege.

Forfatteren har fylt ut ICMJE-skjemaet og oppgir ingen interessekonflikter.

\section{GEIR SAND}

Infeksjonsmedisinsk seksjon

Stavanger universitetssjukehus

Han har bidratt med innsamling og tolkning av data, revisjon og godkjenning av innsendte manusversjon.

Geir Sand er spesialist i infeksjonssykdommer.

Forfatteren har fylt ut ICMJE-skjemaet og oppgir ingen interessekonflikter.

\section{RAISA HANNULA}

Avdeling for infeksjonssykdommer

St. Olavs hospital

Hun har bidratt med innsamling og tolkning av data, revisjon og godkjenning av innsendte manusversjon.

Raisa Hannula er spesialist i infeksjonssykdommer og i mikrobiologi og er avdelingssjef. Forfatteren har fylt ut ICMJE-skjemaet og oppgir ingen interessekonflikter.

\section{NINA LANGELAND}

Klinisk institutt 2

Universitetet i Bergen

og

Nasjonal kompetansetjeneste for tropiske infeksjonssykdommer

Haukeland universitetssjukehus

Hun har bidratt med innsamling og tolkning av data, revisjon og godkjenning av innsendte manusversjon.

Nina Langeland er spesialist i infeksjonssykdommer og professor i infeksjonsmedisin. Forfatteren har fylt ut ICMJE-skjemaet og oppgir ingen interessekonflikter.

\section{KRISTINE MØRCH}

Klinisk institutt 2

Universitetet i Bergen

og

Nasjonal kompetansetjeneste for tropiske infeksjonssykdommer

Haukeland universitetssjukehus

Hun har bidratt med idé, utforming av studien, innsamling og tolkning av data, førsteutkastet av manuskriptet, revisjon og godkjenning av innsendte manusversjon.

Kristine Mørch er spesialist i infeksjonssykdommer, førsteamanuensis og senterleder.

Forfatteren har fylt ut ICMJE-skjemaet og oppgir ingen interessekonflikter. 
Leishmaniasis er en sjelden, men potensielt alvorlig tropisk infeksjonssykdom. Norske klinikere er lite kjent med diagnostikk og behandling av denne sykdommen. Formålet med studien var å undersøke forekomst, diagnostikk og behandling av leishmaniasis ved fem universitetssykehus i Norge.

MATERIALE OG METODE

Forekomst, diagnostikk og behandling av mistenkt leishmaniasis ble registrert prospektivt i perioden mars 2014 - september 2017 ved universitetssykehusene i Bergen, Oslo, Stavanger, Trondheim og Tromsø.

\section{RESULTATER}

13 pasienter med leishmaniasis ble registrert i perioden. Visceral leishmaniasis ble påvist hos to pasienter smittet i middelhavsområdet, etter syv og åtte uker med symptomer. Diagnose ble stilt med serologi samt mikroskopi og/eller polymerasekjedereaksjonstest (PCR) fra milt, blod og benmarg. Begge ble effektivt behandlet med liposomalt amfotericin B. Kutan leishmaniasis ble påvist hos elleve pasienter, og prøve fra ti av disse var positiv ved PCR. To pasienter var smittet med potensielt mukotrope arter. Liposomalt amfotericin B var førstevalg til alle som fikk behandling, men én pasient ble frisk først etter lokalbehandling med natriumstiboglukonat.

FORTOLKNING

Utredning av visceral leishmaniasis ble utført i henhold til internasjonale retningslinjer. Pasientene ble diagnostisert sent i forløpet, sannsynligvis fordi sykdommen er sjelden og lite kjent i Norge. Kutan leishmaniasis ble diagnostisert med PCR, men ingen fikk lokalbehandling som førstevalg, slik det anbefales i egnede tilfeller, sannsynligvis fordi medikamentene er lite tilgjengelige i Norge og administrasjonsmåten med lokal infiltrasjon er lite kjent.

\section{HOVEDFUNN}

Til sammen 13 pasienter ble registrert med leishmaniasis i perioden mars 2014-september 2017.

Visceral leishmaniasis ble diagnostisert sent i forløpet, og pasientene var smittet i middelhavsland, steder klinikere i liten grad assosierer med tropiske infeksjoner.

Visceral leishmaniasis og Leishmania-art med potensial for mukokutan sykdom ble diagnostisert med PCR og sekvensering og effektivt behandlet med liposomalt amfotericin $\mathrm{B}$, i tråd med internasjonale retningslinjer.

Liposomalt amfotericin B, og ikke lokalbehandling, ble gitt som førstevalg også til alle med kutan leishmaniasis.

Leishmaniasis forårsakes av protozoen Leishmania, som tilhører klassen Kinetoplastida, ordenen Trypanosomatida og familien Trypanosomatidae. Leishmania spres via bitt av sandfluer, og avhengig av art er hunder, gnagere og mennesker vanlige reservoarer (1).

Manifestasjonen avhenger av immunstatus og Leishmania-art og varierer fra dødelig forløp ved ubehandlet visceral leishmaniasis til store skader i ansikt og svelg ved mukokutan form og selvbegrensende sår ved kutan form (1).

Visceral leishmaniasis er endemisk i 78 land (2). Insidensen har vært fallende de siste årene, og i 2018 ble det rapportert rundt 17 ooo nye tilfeller. $90 \%$ av disse var i Brasil, Sudan, SørSudan, Etiopia, Kenya, Somalia og India (므). Smitte forekommer imidlertid også i SørEuropa. I en studie blant reisende i Europa i perioden 2000-12 fant man 10 tilfeller av visceral leishmaniasis og 30 tilfeller av kutan leishmaniasis med smittested Spania, Malta 
og Italia (3). Mukokutan form, som vanligvis forårsakes av subgenus Leishmania (Viannia), finnes hovedsakelig i Sør- og Mellom-Amerika, mens den kutane formen hyppigst forekommer i Sør- og Mellom-Amerika, Afrika og Asia. Insidensen av kutan leishmaniasis er $\emptyset$ kende (2).

Den amerikanske foreningen for infeksjonssykdommer (IDSA) publiserte retningslinjer for diagnostikk og behandling i 2016 (4).), og en europeisk ekspertgruppe publiserte anbefalinger for kutan leishmaniasis i 2014 (5). Polymerasekjedereaksjonstest (PCR) og sekvensering er anbefalt for artspåvisning, som gir grunnlag for valg av behandling. Dette var ikke tilgjengelig i Norge som rutinediagnostikk før 2015.

Liposomalt amfotericin B anbefales ved visceral og mukokutan leishmaniasis, mens lokalbehandling anbefales ved kutan form i egnede tilfeller (4,.5). Behandling for kutan leishmanisis må individualiseres, da det ikke finnes evidens som grunnlag for universelle anbefalinger. Medikamenter for lokalbehandling er ikke tilgjengelig i Norge uten registreringsfritak.

Ettersom denne sykdommen er sjelden her i landet og medikamenter er lite tilgjengelig eller beheftet med potensielle bivirkninger, er det risiko for mangelfull håndtering. Formålet med denne studien var å undersøke forekomst, diagnostikk og behandling av leishmaniasis ved fem universitetssykehus.

\section{Materiale og metode}

Pasienter med mistenkt leishmaniasis ved universitetssykehusene i Bergen, Oslo (Ullevål), Stavanger, Trondheim og Troms $\emptyset$ ble inkludert prospektivt i perioden 1.3.2014-30.9.2017. Det var i utgangspunktet planlagt inklusjon av 50 pasienter for å sammenlikne PCR-metoder. I 2015 ble PCR innført som rutinediagnostikk ved Ullevål sykehus, og behovet for metodeutvikling var dermed mindre. Metodeutviklingsdelen av studien ble derfor avsluttet, men man fortsatte å beskrive forekomst, diagnostikk og behandling av leishmaniasis i Norge over en treårsperiode. Opplysninger om manifestasjon, smittested, immunstatus, diagnostikk, behandling og utfall ble registrert.

Mikroskopi ble utført lokalt, og studiesykehusene bestemte selv hvor de skulle sende prøver for videre analyse og artsbestemmelse. Ved Oslo universitetssykehus, Ullevål ble sanntids-PCR med 18S rDNA som målgen brukt for påvisning, og sekvensering av hsp7ogenet ble brukt for artsidentifikasjon ( $\underline{6}$ ). Ved Folkhälsomyndigheten ble en ikkeartsspesifikk serologi utført med $L$. (L.) donovani som antigen, konvensjonell PCR ble utført med 18S rDNA som målgen, og artsidentifikasjon ble utført ved hjelp av restriksjonsfragmentlengdepolymorfisme (RFLP).

Ved Kompetansetjenesten for tropiske infeksjonssykdommer ble det i tillegg til rutinediagnostikk gjort PCR med $18 \mathrm{~S} r D N A$ (7.) og $A A P_{3}$ (arginin permease 3 ) (모) som målgen. Prøvemateriale som benmarg, EDTA (etylendiamintetraacetat)-blod, miltbiopsi, stansebiopsi, finnålsbiopsi og absorberende filterpapir trykket i sårbunn (Whatman FTA, Sigma-Aldrich, St. Louis, USA) (se appendiks på tidsskriftet.no) ble samlet inn avhengig av klinisk presentasjon.

ETIKK

Pasienter samtykket skriftlig til å delta i studien. Studien ble godkjent av Regional etisk komité (godkjenningsnummer: 2014/805).

\section{Resultater}


13 pasienter ble registrert med leishmaniasis i perioden. To hadde visceral leishmaniasis forårsaket av Leishmania (L.) infantum. Begge var eldre mennesker (> 70 år) smittet i middelhavsområdet, hvorav én, som tidligere er omtalt i Tidsskriftet, var

immunsupprimert med metotreksat grunnet revmatoid artritt (9). Begge hadde langvarig feber, vekttap, splenomegali, forhøyet senkning og CRP, pancytopeni, hypoalbuminemi og hypergammaglobulinemi.

Kutan leishmaniasis ble påvist hos elleve pasienter. To var smittet i Mellom-Amerika med de potensielt mukotrope artene L. (Viannia) braziliensis og L. (V.) naiffi, men ingen av disse utviklet mukokutan leishmaniasis. Fem var smittet i middelhavsland med $L$. (L.) tropica, $L$. (L.) infantum eller $L$. (L.) major, to med $L$. (L.) major i Midtøsten og to med $L .(L$.$) mexicana i$ Mellom-Amerika. Fire pasienter hadde to eller færre sår, mens syv hadde flere enn to sår. Ti pasienter hadde sår i eksponerte områder for vektoren, som ansikt og ekstremiteter, mens én pasient hadde mer atypiske multiple sår.

\section{DIAGNOSTIKK}

Pasientene med visceral leishmaniasis hadde positiv serologi og fikk påvist parasitter ved PCR og/eller mikroskopi av miltbiopsi (figur 1) og benmarg. Begge fikk også påvist Leishmania ved PCR-analyse av fullblod.

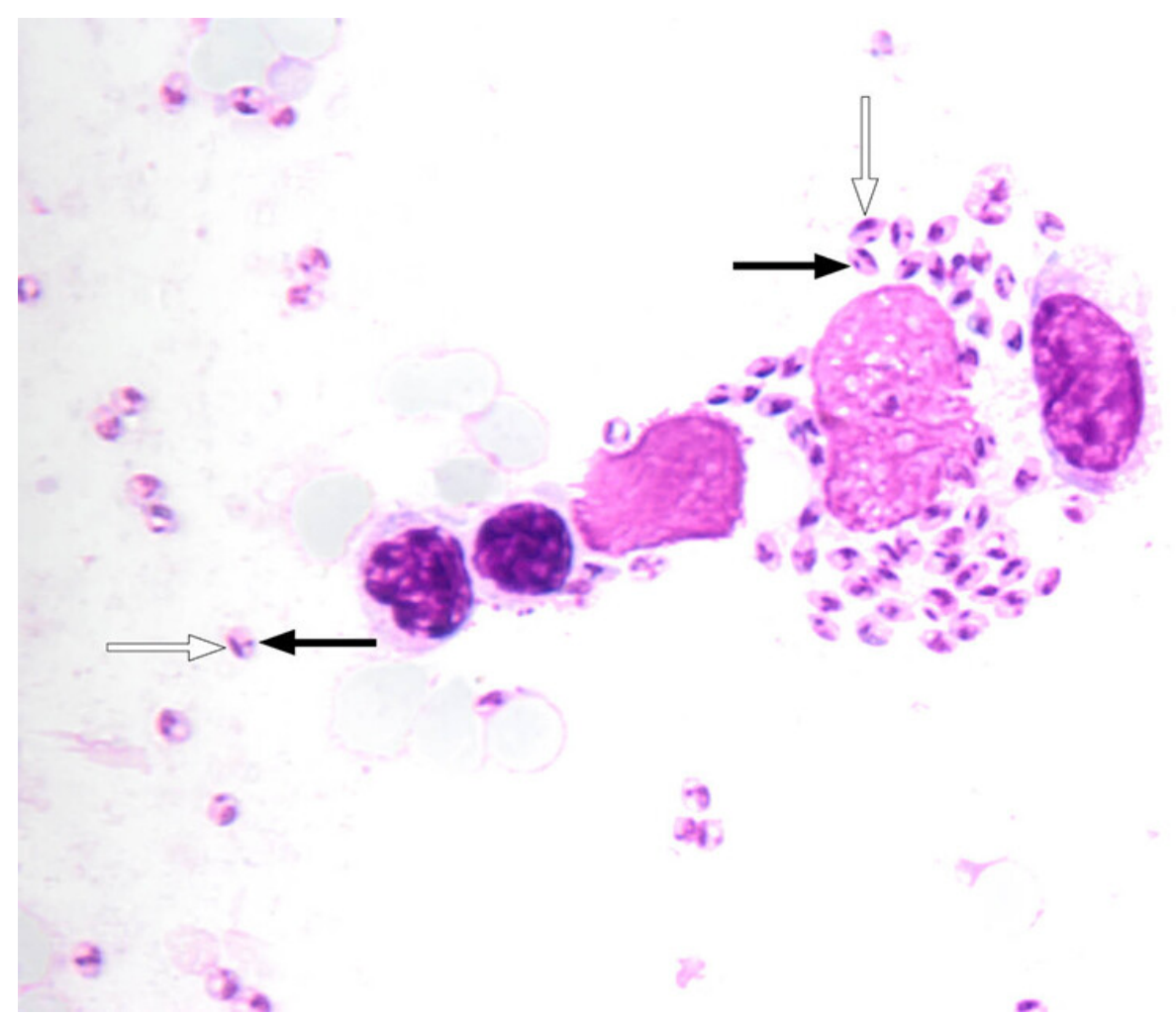

Figur 1 Lysmikroskopi av miltbiopsi fra pasient med Leishmania-amastigoter, der en kan se cellekjerne (hvit pil) og den karakteristiske kinetoplasten (sort pil).

Ti pasienter med kutan leishmaniasis fikk påvist Leishmania-art med PCR i stansebiopsi ( $\mathrm{N}=$ 9) eller såravskrap. Mikroskopi påviste parasitter hos fem av seks pasienter med positiv PCR-test. Én pasient hadde negativ PCR-test, men ble diagnostisert med L. (L.) majorinfeksjon ut fra eksponering. Utredning ble gjort i tråd med retningslinjer $(4,5)$.

Prøvemateriale fra 11 pasienter ble innsendt for sammenlikning av PCR-metoder. To ulike målgen ble brukt ved PCR-test: $18 S$ rDNA og AAP3. Det ble påvist Leishmania i flere tilfeller ved bruk av $18 S$ rDNA enn ved bruk av $A A P_{3}$ (appendiks).

\section{BEHANDLING}

Pasientene med visceral leishmaniasis fikk behandling med liposomalt amfotericin B, som anbefalt i retningslinjene (4). Begge ble friske. Kumulativ dose liposomalt amfotericin B til pasienten med immunsvikt var $44 \mathrm{mg} / \mathrm{kg}$ (4 mg/kg dag 1-6, 11, 17, 24, 31 og 38 ). 
Alle som fikk medikamentell behandling for kutan leishmaniasis $(\mathrm{N}=8 / 11)$ ble behandlet med liposomalt amfotericin B som førstevalg. Syv fikk kumulativ dose $18 \mathrm{mg} / \mathrm{kg}(3 \mathrm{mg} / \mathrm{kg}$ dag 1-5 og 10). Standard anbefaling for dosering av liposomalt amfotericin B ved kutan leishmaniasis er ikke etablert, men den gitte doseringen samsvarte med forslag fra internasjonale retningslinjer (4). Én pasient med $L$. (L.) infantum-infeksjon responderte ikke på liposomalt amfotericin $\mathrm{B}$, men ble frisk etter lokalbehandling med natriumstiboglukonat ( $4 \mathrm{~mL}$ à $100 \mathrm{mg} / \mathrm{mL}$ ) i kombinasjon med kryoterapi (figur 2) gitt i tråd med behandlingsanbefalinger $(\underline{4}, 5)$. Hos tre pasienter med $L$. (L.) major eller $L$. (L). infantum-infeksjon tilhelte sårene spontant uten behandling.

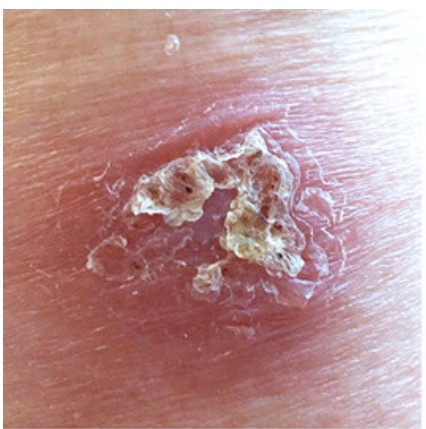

a

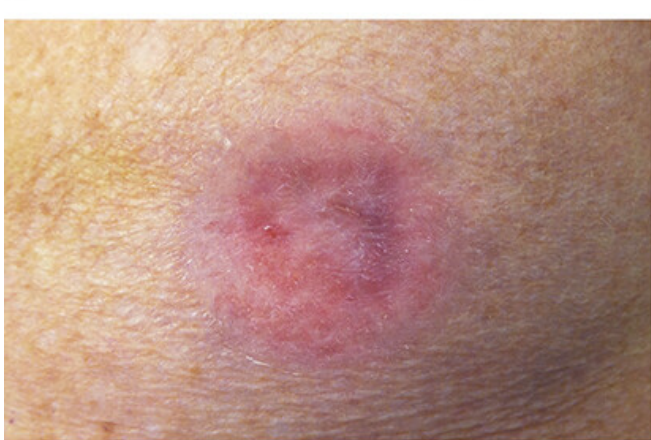

d

b
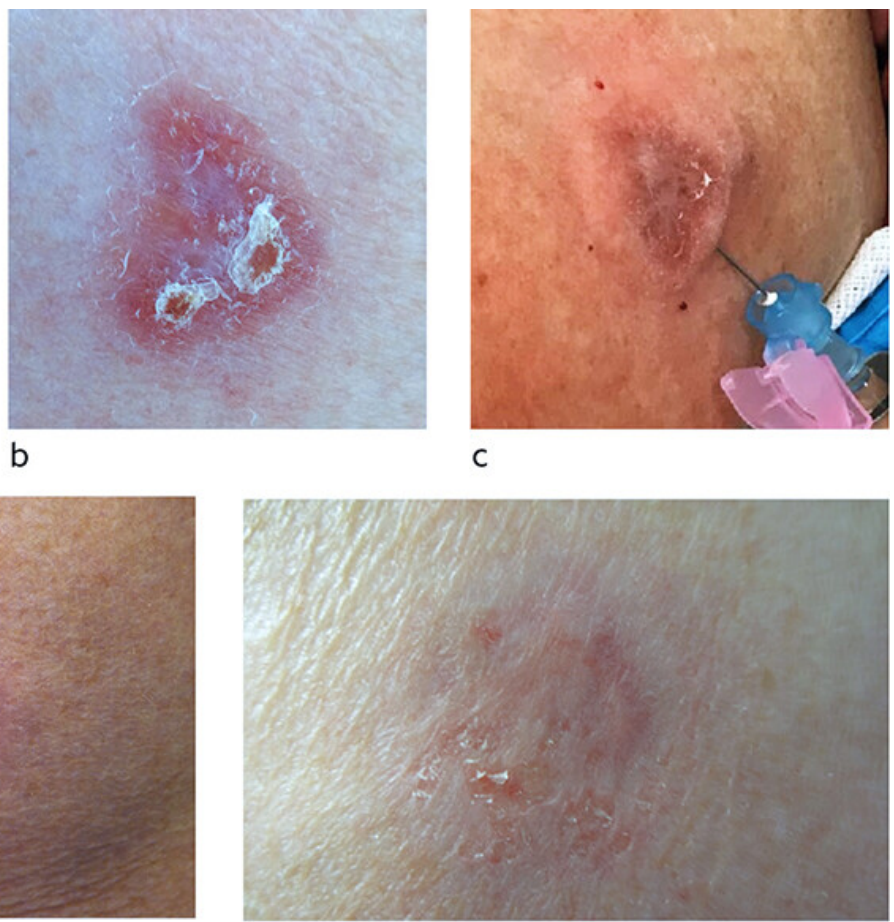

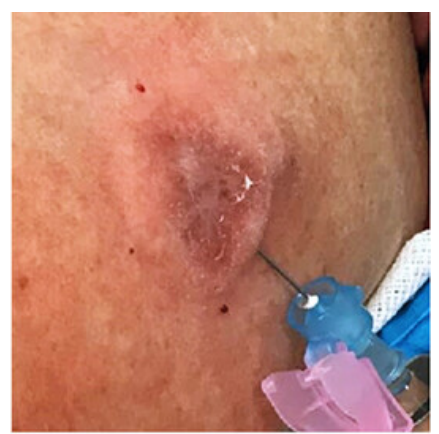

C

Figur 2 Kutan leishmaniasis på overarm forårsaket av L. (L.) infantum. a) før liposomalt amfotericin B, b) syv måneder etter liposomalt amfotericin B, c) lokalbehandling med natriumstiboglukonat ett år etter liposomalt amfotericin B, d) to uker etter første lokalbehandling og før andre lokalbehandling, e) én måned etter lokalbehandling.

\section{Diskusjon}

\section{FOREKOMST, SMITTESTED OG FUNN}

Pasientene med visceral leishmaniasis hadde klassiske symptomer i form av langvarig feber, vekttap, forstørret milt, pancytopeni og hypergammaglobulinemi (1), men det tok tid før de fikk riktig diagnose og behandling. De ble smittet i middelhavsområdet, hvor $L$.

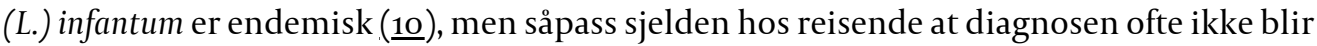
vurdert før sent i forløpet. I Madrid-regionen har det imidlertid de senere årene vært relativ høy forekomst av infeksjon med L. (L.) infantum (1ㅡ). Visceral leishmaniasis i Norge hos pasienter smittet i Spania har også vært rapportert tidligere (12,13). Én av pasientene fra denne studien er også tidligere beskrevet i en kasuistikk i Tidsskriftet (9.). Med økende reisevirksomhet og flere flyktninger fra endemiske områder er det sannsynlig at forekomsten av leishmaniasis vil øke i Norge (1) $),(\underline{14}, 15)$.

Pasientene med visceral leishmaniasis i denne studien var eldre mennesker, og en av dem brukte immundempende medisiner. Immunsvikt er en kjent risikofaktor for visceral leishmaniasis, og det er økende forekomst av denne formen hos reisende med immunsvekkelse $(\underline{15}, \underline{16})$. 
Pasientene med visceral leishmaniasis hadde positiv serologi og fikk påvist parasitter ved PCR og/eller mikroskopi i blod og vev. Generelt anbefales utredning med serologi og PCR, mikroskopi og eventuelt dyrkning fra benmarg, milt, lymfeknute, lever eller blod, der PCR er mest sensitiv (4). Miltaspirat er gullstandard, men har en viss risiko for blødningskomplikasjon (1 av 5 ooo), og benmargsunders $\varnothing$ kelse foretrekkes ofte $(4,17$.). PCR fra blod er nyttig, og våre funn er i samsvar med studier der det er rapportert at denne

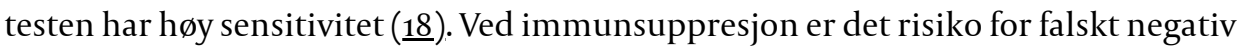
serologi, og i disse tilfellene er PCR spesielt nyttig (4).

Pasientene med kutan leishmaniasis fikk påvist art ved sekvensering (4). Ved kutan og mukokutan leishmaniasis anbefales PCR, mikroskopi og eventuelt dyrkning fra sår eller slimhinne $(4,19$.$) . Molekylærdiagnostiske metoder er mest sensitive og er nødvendige for$ artsbestemmelse. Ved smitte i Sør- og Mellom-Amerika er artsbestemmelse spesielt viktig, da subgenus Leishmania (Viannia) kan føre til mukokutan leishmaniasis (4). Kun én pasient hadde negativ PCR-test i denne studien, sannsynligvis grunnet lavt antall parasitter fordi sårene var i spontan bedring.

Stansebiopsi fra sårkant, finnålsbiopsi fra sårkant eller såravskrap anbefales som prøvemateriale $(4,19$.$) . I denne studien ble stansebiopsi gjort som rutinediagnostikk, i tråd$ med anbefalingene. Ved tilleggsundersøkelser var PCR fra stansebiopsi positiv i flest tilfeller sammenliknet med annet prøvemateriale med mindre volum vev (appendiks). Filterpapir trykket direkte i sårbunnen er praktisk for prøvetaking og forsendelse, men PCR-test var negativ for to av fem slike prøver i denne studien (appendiks).

\section{BEHANDLING}

Anbefalt behandling for immunkompetente pasienter med visceral leishmaniasis er liposomalt amfotericin B $3 \mathrm{mg} / \mathrm{kg}$ intravenøst dag 1-5, 14 og 21 (4). Ved immunsvikt anbefales en kumulativ dose på $40 \mathrm{mg} / \mathrm{kg}$. Pasientene med visceral leishmaniasis responderte effektivt på liposomalt amfotericin B uten å få alvorlige bivirkninger.

I endemiske områder er liposomalt amfotericin B ofte utilgjengelig på grunn av høy pris og behov for kjølig oppbevaring, og miltefosin, natriumstiboglukonat (Pentostam) og paromomycin er andre alternativer (1). I flere land i Asia og Afrika har monoterapi med miltefosin og natriumstiboglukonat blitt erstattet med kortere kurer og kombinasjonskurer med andre preparater grunnet $\emptyset$ kende resistens og behandlingssvikt, men effekten av de nye kurene varierer mellom regionene (므).

Ved kutan leishmaniasis hos immunkompetente personer infisert med en Leishmania-art som ikke er assosiert med mukokutan leishmaniasis, og der sårene er få og små, anbefaler man å avvente behandling i påvente av spontan tilheling (4,.5). Spontan tilheling kan ta 215 måneder (21). Skal sårene behandles, har man valget mellom lokalbehandling med natriumstiboglukonat (figur 2), kryoterapi, varmebehandling eller systemisk behandling (4,.5).Ved multiple eller store sår, sår i ansikt og ved smitte med art med potensial for mukokutan leishmaniasis, anbefales systemisk behandling (4,5).

Alle pasientene som fikk behandling $(\mathrm{N}=8 / 11)$ i denne studien, fikk liposomalt amfotericin B som førstevalg også i tilfeller der retningslinjene anbefaler lokalbehandling (4,5). Systemisk behandling er dyrt og har potensielt alvorlige bivirkninger, men midler for lokalbehandling er mindre tilgjengelige, injeksjoner er smertefulle og metodikken lite kjent blant klinikere, noe som sannsynligvis forklarer at denne metoden er mindre brukt. Liposomalt amfotericin B har mindre effekt ved den kutane formen enn den viscerale, sannsynligvis på grunn av lavere konsentrasjon av medikamentet $\mathrm{i}$ hud. Etablerte anbefalinger for liposomalt amfotericin B ved kutan leishmaniasis basert på kontrollerte studier finnes foreløpig ikke (1ํ). I en fransk studie av kutan og mukokutan leishmaniasis var liposomalt amfotericin B effektivt hos kun $46 \%$ (19/41) (22). I tråd med dette fant vi manglende effekt av liposomalt amfotericin B hos én pasient med $L$. (L.) infantum-infeksjon (figur 2). Denne pasienten responderte på to behandlingsrunder med to ukers intervall med intrakutan injeksjon av natriumstiboglukonat i kombinasjon med kryoterapi. 
Oppfølging med tanke på manglende respons etter tre måneder eller senere residiv anbefales i minst ett år for kutan leishmaniasis og $\mathrm{i}$ ti år for potensiell mukokutan leishmaniasis (1,4). Etter behandlet visceral leishmaniasis forblir parasittene latent $\mathrm{i}$ kroppen resten av livet, med risiko for residiv ved immunsuppresjon. Det finnes ikke biokjemiske parametre som kan monitorere for residiv. Vi anbefaler at pasienter som er kurert, er oppmerksom på symptomer på oppbluss av sykdommen. De bør ikke være blodgivere (4).

KONKLUSJON

Pasientene med visceral leishmaniasis ble effektivt behandlet, men diagnostisert sent $\mathrm{i}$ forløpet. Kutan leishmaniasis ble utredet i tråd med anbefalinger, men liposomalt amfotericin B fremfor lokalbehandling ble gitt i større grad enn anbefalt i retningslinjer.

Artikkelen er fagfellevurdert.

\section{LITTERATUR}

1. Burza S, Croft SL, Boelaert M. Leishmaniasis. Lancet 2018;392: 951-70. [PubMed][CrossRef]

2. Ruiz-Postigo JA, Grout L, Saurabh J. Global leishmaniasis surveillance, 2017-2018, and first report on 5 additional indicators. Wkly Epidemiol Rec 2020; 65: 265-80.

3. Ehehalt U, Schunk M, Jensenius $M$ et al. Leishmaniasis acquired by travellers to endemic regions in Europe: a EuroTravNet multi-centre study. Travel Med Infect Dis 2014; 12: 167-72. [PubMed][CrossRef]

4. Aronson N, Herwaldt BL, Libman M et al. Diagnosis and Treatment of Leishmaniasis: Clinical Practice Guidelines by the Infectious Diseases Society of America (IDSA) and the American Society of Tropical Medicine and Hygiene (ASTMH). Clin Infect Dis 2016; 63: 1539-57. [PubMed][CrossRef]

5. Blum J, Buffet P, Visser L et al. LeishMan recommendations for treatment of cutaneous and mucosal leishmaniasis in travelers, 2014. J Travel Med 2014; 21: 116-29. [PubMed][CrossRef]

6. Van der Auwera G, Maes I, De Doncker S et al. Heat-shock protein 70 gene sequencing for Leishmania species typing in European tropical infectious disease clinics. Euro Surveill 2013; 18: 20543. [PubMed][CrossRef]

7. Uliana SR, Nelson K, Beverley SM et al. Discrimination amongst Leishmania by polymerase chain reaction and hybridization with small subunit ribosomal DNA derived oligonucleotides. J Eukaryot Microbiol 1994; 41:324-30. [PubMed][CrossRef]

8. Tellevik MG, Muller KE, Løkken KR et al. Detection of a broad range of Leishmania species and determination of parasite load of infected mouse by real-time PCR targeting the arginine permease gene AAP3. Acta Trop 2014; 137: 99-104. [PubMed][CrossRef]

9. Blomberg B, Müller KE, Helgeland L et al. En mann i 8o-årene med leddgikt og vedvarende feber. Tidsskr Nor Legeforen 2019; 139. doi:10.4045/tidsskr.18.0546. [PubMed][CrossRef]

10. Ready PD. Leishmaniasis emergence in Europe. Euro Surveill 2010; 15:19505. [PubMed]

11. Arce A, Estirado A, Ordobas M et al. Re-emergence of leishmaniasis in Spain: community outbreak in Madrid, Spain, 2009 to 2012. Euro Surveill 2013; 18: 20546. [PubMed][CrossRef]

12. Besada E, Njålla RJ, Nossent JC. Imported case of visceral leishmaniasis presenting as pancytopenia in a Norwegian patient treated with methotrexate and etanercept for psoriasis arthritis. Rheumatol Int 2013; 33: 2687-9. [PubMed][CrossRef]

13. Moser KH, Rødevand E, Hammerstrøm J et al. En tidligere frisk mann med feberepisoder med kirkespirforløp. Tidsskr Nor Laegeforen 2008; 128: 1845-7. [PubMed]

14. Söbirk SK, Inghammar M, Collin M et al. Imported leishmaniasis in Sweden 1993-2016. Epidemiol Infect 2018; 146: 1267-74. [PubMed][CrossRef]

15. Schwartz T, Jensenius M, Blomberg B et al. Imported visceral leishmaniasis and immunosuppression in seven Norwegian patients. Trop Dis Travel Med Vaccines 2019; 5: 16. [PubMed] [CrossRef] 
16. Fletcher K, Issa R, Lockwood DNJ. Visceral leishmaniasis and immunocompromise as a risk factor for the development of visceral leishmaniasis: a changing pattern at the hospital for tropical diseases, london. PLoS One 2015; 10: e0121418. [PubMed][CrossRef]

17. Sundar S, Rai M. Laboratory diagnosis of visceral leishmaniasis. Clin Diagn Lab Immunol 2002; 9: 951-8. [PubMed]

18. de Ruiter CM, van der Veer C, Leeflang MMG et al. Molecular tools for diagnosis of visceral leishmaniasis: systematic review and meta-analysis of diagnostic test accuracy. J Clin Microbiol 2014; 52:3147-55. [PubMed][CrossRef]

19. Centers for Disease Control and Prevention. Practical guide for specimen collection and reference diagnosis of leishmaniasis.

https://www.cdc.gov/parasites/leishmaniasis/resources/pdf/cdc_diagnosis_guide_leishmaniasis_201 6.pdf Lest 11.1.2021.

20. Alves F, Bilbe G, Blesson S et al. Recent development of visceral leishmaniasis treatments: Successes, pitfalls, and perspectives. Clin Microbiol Rev 2018;31: eooo48-18. [PubMed][CrossRef]

21. Reithinger R, Dujardin JC, Louzir H et al. Cutaneous leishmaniasis. Lancet Infect Dis 2007; 7: 58196. [PubMed][CrossRef]

22. Guery R, Henry B, Martin-Blondel G et al. Liposomal amphotericin B in travelers with cutaneous and muco-cutaneous leishmaniasis: Not a panacea. PLoS Negl Trop Dis 2017; 11: eooo6o94. [PubMed] [CrossRef]

Publisert: 22. februar 2021. Tidsskr Nor Legeforen. DOI: 10.4045/tidsskr.19.0171

Mottatt 24.2.2019, første revisjon innsendt 29.11.2020, godkjent 11.1.2021.

(C) Tidsskrift for Den norske legeforening 2023. Lastet ned fra tidsskriftet.no 26. april 2023. 